Article

\title{
The Traces of the Bhagavad Gita in the Perennial Philosophy-A Critical Study of the Gita's Reception Among the Perennialists
}

\author{
Mohammad Syifa Amin Widigdo 1,2 (1) \\ 1 Faculty of Islamic Studies, Universitas Muhammadiyah Yogyakarta, Yogyakarta 55183, Indonesia; \\ syifamin@umy.ac.id \\ 2 Wonderhome Library, Yogyakarta 55294, Indonesia
}

Received: 14 April 2020; Accepted: 28 April 2020; Published: 6 May 2020

check for updates

\begin{abstract}
This article studies the reception of the Bhagavad Gita within circles of Perennial Philosophy scholars and examines how the Gita is interpreted to the extent that it influenced their thoughts. Within the Hindu tradition, the Gita is often read from a dualist and/or non-dualist perspective in the context of observing religious teachings and practices. In the hands of Perennial Philosophy scholars, the Gita is read from a different angle. Through a critical examination of the original works of the Perennialists, this article shows that the majority of the Perennial traditionalists read the Gita from a dualist background but that, eventually, they were convinced that the Gita's paradigm is essentially non-dualist. In turn, this non-dualist paradigm of the Gita influences and transforms their ontological thought, from the dualist to the non-dualist view of the reality. Meanwhile, the non-traditionalist group of Perennial Philosophy scholars are not interested in this ontological discussion. They are more concerned with the question of how the Gita provides certain ways of attaining human liberation and salvation. Interestingly, both traditionalist and non-traditionalist camps are influenced by the Gita, at the same time, inserting an external understanding and interpretation into the Gita.
\end{abstract}

Keywords: Bhagavad Gita; Perennial Philosophy; Atman; Maya; non-dualist; dualist; Advaita; Dvaita; Samkhya

\section{Introduction}

The Baghavad Gita, as "the sacred book of the east" ${ }^{1}$, has been not only revered within Hindu tradition but also received, read, and interpreted by philosophers, clerics, and scholars beyond the Hindu community and religion. In Hindu tradition, the Gita is mainly read to understand the foundational concepts of religion, to observe religious teachings and practices, or to attain human liberation (Dhiman 2013; Stroud 2005; Patil 1960; Shideler 1960; McLain 2019; Theodor 2017). Some scholars would employ a dualistic perspective of Gita's interpretation to achieve these religious objectives. From this perspective, Krishna is traditionally viewed as the avatar of Vishnu (Gonda 1969, p. 157; Bhaskarananda 2002). Krishna is the divine incarnation and the human form of the formless God, Vishnu, who comes to the world to liberate humans and help them attain perfection (Bhaskarananda 2002). However, some other Hindu scholars hold the opposite view. They use a non-dualistic perspective, arguing that the Reality is beyond both the formless Vishnu and Krishna's countless forms (Easwaran 2011, p. 48; Kriyananda and Yogananda 2006). A form of divinity is

1 The term has been introduced by Friedrich Max Muller in 1882 when he edited volumes of the sacred book of the east, which included the Bhagavad Gita (See, Muller 1903; Sinha 2010, pp. 304-5). 
deemed the outer layer of reality that is accessible to humans through sensory perception. However, if an observer goes beyond his sensory perception, practices spiritual exercises, and attains spiritual disclosure, he will be overwhelmed to find the timeless, unchangeable, infinite, and formless divinity beyond various forms of Krishna or formless Vishnu.

Meanwhile, outside the Hindu community, the reception of the Gita spreads across religious, philosophical, and scholarly tradition (Davis 2015; Sinha 2010; Eder 1988; Ashton 2014). However, the study of the reception of the Gita among Perennial Philosophy circles is lacking, although the study of the Perennialist's reception is valuable in terms of gaining a new perspective and understanding from scholars and philosophers from different religious backgrounds. Perennial scholars and philosophers are those who focus their study primarily on the divine Reality (Huxley 1945) and on the Perennial wisdom among religions (i.e., sophia perennis and religio perennis). ${ }^{2}$ These scholars present the Gita from an ambiguous but interesting perspective, reflecting a dualist and non-dualist interpretation of the Gita.

On the one hand, they understand the peculiar teachings of the Gita, especially its non-dualist concept of reality (although the Gita can be read from the dualist angle as well). On the other hand, they have to bring such a non-dualist perspective in the context in which the dualist paradigm is prevalent. ${ }^{3}$ In this regard, this article aims to trace and analyze how some peculiar teachings of the Gita are interpreted and presented by those Perennial Philosophy scholars to their audience. There are two main groups of Perennial Philosophy writers whose ideas will be discussed here. First, those who consider themselves as Perennial-traditionalists ${ }^{4}$ such as Rene Guenon (1886-1952), Ananda K. Coomaraswamy (1877-1947), Frithjof Schuon (1907-1998), and Seyyed Hossein Nasr (1933-Present). Second, those who do not belong to the first group but have the same interests as them, and are even spiritually or intellectually influenced by them, such as Aldous Huxley (1894-1963) and Huston Smith (1919-2016).

\section{The Perennial Philosophy}

Perennial Philosophy (philosophia perennis) is a philosophical school that emphasizes its thoughts on, intellectual exploration of, and metaphysical discernment of the primordial, essential, and universal aspects of religions. Frithjof Schuon (Schuon 2007), as one of the pioneers of the Perennial philosophy, believes that these primordial, essential, and universal aspects do not belong to a specific system of belief. They are shared by all dogmas and all expressions of wisdom. For example, all religions and beliefs are concerned with the discernment of the Real from the illusory. In Abrahamic religions, the Real may appear in the concept of God. In Hinduism, the Real is represented by the notion of Atman, which is differentiated from Maya. God or Atman is the sole divine reality that is different from others, the illusory ones. Deeper and pure intellection is required to differentiate the Real from the illusory when the Divine Reality becomes flesh (Jesus in the context of Christianity), when the divine will is embodied in words (the Qur'an in Islam), when God and His chosen people are inseparable (God of Israel in Judaism), or when the Real appears in countless different forms (Atman and its relation with Maya in Hinduism).

2 In their view, the divine Reality is perceived as both the absolute Truth and infinite Presence. As absolute Truth, it is the Perennial wisdom (sophia perennis) that stands as the transcendence source of all the intrinsically orthodox religions of human kind. As infinite Presence, it is the Perennial religion (religion perennis) that lives within the heart of all intrinsically orthodox religions (See, Minaar and Ling 2007, p. xii).

3 In the Perennial philosophy, reality, or especially religion, is generally conceived as having two dimensions, namely esoteric and exoteric dimension. Furthermore, philosophers also divide beings into a number of pairs, such as necessary being and contingent being, the Absolute and the relative, and the Real and the illusory.

4 They call themselves as traditionalists because they believe in what Seyyed Hossein Nasr calls "a Primordial Tradition" which constituted original or archetypal man's primal spiritual and intellectual heritage. This Primordial Tradition is then believed to be reflected in all later various religious traditions. 
In this regard, according to Aldous Huxley (Huxley 1945), the Perennial philosophy "is primarily concerned with the one, divine Reality substantial to the manifold world of things and lives and minds". This divine Reality becomes the transcendent source of all religions and, at the same time, resides within the heart of these religions. In this respect, there is a so-called "transcendent unity" of all religions. The Perennial philosophy could see this transcendent unity, for example, in Hinduism, Buddhism, Judaism, Christianity, or Islam, without denying the differences and peculiarities of those religions.

The Perennial philosophy has two primary schools of thought: one, philosophers who focus their study and intellectual exploration on the transcendent unity of religions, the underlying religions, or the heart of all religions. They are called the traditionalist group of the Perennial philosophers. Two, those who focus on the embodiments, expressions, and ways that the divine Reality provides for humans to access, learn, and have an interaction. They are called the non-traditionalist group of the Perennial philosophers.

\section{The Perennial-Traditionalists and the Gita}

As explained by the master of the Perennial-traditionalists, Frithjof Schuon, reality is divided into two; the Real and the illusory (Schuon 2005c, p. 68). In turn, the task of the human intellect is to discern such duality. It means to distinguish the Real from the illusory, the Absolute from the contingent, or the Necessary from the possible (Schuon 2007, p. 243). Similarly, religion is also perceived as possessing this kind of duality, namely the exoteric and the esoteric dimensions of religion. The exoteric is concerned with the external and formal aspects of religion, whereas the esoteric deals with the formless and essential elements of it (Nasr 2007c, pp. 23-24). According to (Nasr 2007c, p. 24)), within the range of this exoteric-esoteric dimension, there is a kind of hierarchy ranging from the most illusory to the most real, from the most outward to the most inward. The above understanding of reality and religion influences the Perennial philosophers in approaching the Bhagavad Gita and its contents.

Titus Burckhardt, for example, considers the Bhagavad Gita as an "Oriental Scripture" (Burckhardt 2003, p. 73), as Westerners view the Bible as their scripture. This implies an exoteric understanding of the Gita since the term "scripture" is primarily related to the outer, the material, or the textual dimension of the sacred text. In addition, Seyyed Hossein Nasr seems to recognize the Gita from the esoteric point of view. To him, there is so-called "religious character" in the Gita that one must be aware of. He says, "One cannot seriously read the Bhagavad-Gita in this day and age without becoming aware of the religious character of this text" (Nasr 2007a, p. 6). Given the significant status of the Gita, as a scripture and a text containing a religious character, it is furthermore understandable when the Gita is commonly memorized by people. Ananda K. Coomaraswamy reports that the Gita is well-preserved by Indians through memorization, "There are hundreds of thousands of Indians even now who daily repeat by heart either the whole or some large parts of the Bhagavad Gita" (Coomaraswamy 2004a, p. 59). Thus, the traditionalists' view of the Gita, which recognizes both internal and external aspects of it, seems to be objective in the sense that it does not contradict the way in which the Vedantic (Hindu) tradition views the Gita. ${ }^{5}$

\section{The Gita Verses in Traditionalists' Works}

In addition to the above traditionalists' perception of the Gita, there are occasions in which the Bhagavad Gita is also quoted, presented, interpreted, or referred to in their works in various contexts. For example, S.H. Nasr compares the notion of free will and determinism in Abrahamic religions with the concept of "correct action" in the Bhagavad Gita (Nasr 2007b, p. 130). He argues that the Gita provides an interesting concept of human agency, a balance between the role of individuality and God

5 The Bhagavad Gita is deemed the best commentary on the Vedanta philosophy and widely read by the followers of Vedanta/Hinduism (See, Vivekananda 1986, p. 232). 
in human action. Unfortunately, he does not elaborate further on his understanding of Karma-Yoga as the central concept of action in the Gita.

Another discussion of the Gita takes place in Frithjof Schuon's work. In his essay about Hinduism, F. Schuon discusses the issue of caste, which in his opinion should be placed in the context of dharma, the "law". He quotes from the Gita a verse dealing with the dharma that should be performed by a person in a particular caste: "Better for each one is his own law of action, even if it be imperfect, than the law of another, even well applied. It is better to perish in one's own law; it is perilous to follow the law of another (the Bhagavad Gita, 3. 35)" (Schuon 2005b, p. 203). In this verse, he translates (or uses other's translation) the term svadharma as one's law of action which seems to be acceptable. In fact, the Gita helps Schuon to explain the Hindu social order in general and the relationship between the "caste" and the sva-dharma in particular.

In addition to Nasr and Schuon, another Perennialist who is highly influenced by the Gita is Ananda K. Coomaraswamy. Indeed, compared to his fellow Perennialists, he is likely the most Gita-influenced writer based on his frequent quotation of and reference to the Gita. He refers to the Gita in discussing a number of issues ranging from theology to human paths in attaining the truth. In the discussion of theology in Hinduism, for example, he provides a theistic understanding of the Gita by saying that God (Atman) is "both inside and outside (bahir antas ca bhutanam)" and "undivided in divided beings" (Coomaraswamy 2004b, p. 275). ${ }^{6}$ Coomaraswamy, in addition, holds the idea that God is omnipresent, which is a sort of pantheistic understanding of the Gita. In this regard, by referring to the verse 13.27 , he believes that one in a certain level of understanding can see "the Self, the Lord, alike in all beings and all beings alike in that Lordly Self ... "7. Furthermore, he also notices the similarity and the closeness of God to other beings in the below verse: "The same $\mathrm{I}$ am in all beings, of whom there is none I love and none I hate" ${ }^{\prime 8}$. This theological perspective is a result of Coomaraswamy's non-dual paradigm, which, in fact, is the result of Gita's influence. This pantheistic theological understanding resembles the ideas of the non-dualist school of philosophy within Hinduism, namely Advaita philosophy. Advaita has the view that brahman, as both immanent and transcendent, resides in all beings (Rambachan 2006, pp. 112-13).

Moreover, the influence of the Gita on Coomaraswamy can also be recognized in his departure from Maitri Upanishad's dualistic tenet into the non-dualistic disposition of the Gita. In the Maitri Upanishad, the reality is described consisting of pairs, such as the manifested and unmanifested God, the soul and body, or the illusory world of Maya and the absolute reality of Brahman (Adhikari 2016). The following is Coomaraswamy's statement regarding the necessity of moving away from a dualistic view: "Here under the Sun, we are "overcome by pairs" (Maitri Upanisad III.1); here "every being in the emanated-world moves deluded by the mirage of contrary-pairs, of which the origin is in our liking and disliking ... But to those who are freed from this delusion of the pairs ... freed from the pairs that are implied by the expression of "weal" and "woe", these reach the place of invariability (Bhagavad Gita 7.12-28 and 15.5)"'" (Coomaraswamy 2007b, p. 188). This quotation shows that the Gita's influence in Coomaraswamy's work is quite strong.

Furthermore, the Bhagavad Gita inspires A.K. Coomaraswamy to have an inclusive view, in the sense that he is able to see a path other than the non-dualist path as deserving a divine acceptance or a reward from God. He quotes the Bhagavad Gita (7.21) in which Sri Krishna proclaims: "If any lover whatsoever seeks with faith to worship any form (of God) whatever, it is I who am the founder of his faith," and (4.11), "However men approach Me, even do I reward them, for the path men take from every side is Mine" (Coomaraswamy 2007a, p. 225). In this regard, although his basic philosophical

\footnotetext{
He refers to the verse 13.15 and 16, the verse 15.16 and 17, and the verse 18.20 from the Bhagavad Gita. Ibid, p. 278. It refers to BG. 13.27.

Ibid, p. 282. It refers to verse 9.29 .
} 
disposition is non-dualist, Coomaraswamy also acknowledges the possibility of other ways to attain the Absolute.

Nevertheless, Coomaraswamy also acknowledges that there are two ways that are preferred and supported by the Gita, namely "Karma-Samnyasa" and "Karma-Yoga". Coomaraswamy translates these two ways as "Gnosis" and "Work", respectively. They are considered the same in the sense that both will lead human beings to the Supreme. He quotes the following verse from the Gita (5.4-5): "It is the children of this world, not the men of learning who think of gnosis and works as different" (Coomaraswamy 2004c, p. 84). One who sees that the way of gnosis (Karma-Samnyasa) and work/action (Karma Yoga) are one and the same is deemed capable of seeing the truth.

Apart from that, what can be inferred from the above quotations and interpretations of the Gita is that some Perennialists are, to some extent, informed and influenced by the Bhagavad Gita. This influence makes them not only aware of the existence of a non-dualist perspective within Hinduism but also inspires them to find an analogous concept representing the non-dualist perspective in other religious or philosophical traditions. For example, Coomaraswamy finds that scholars from various religions such as Augustine, Erigena, Eckhart, Dante, Jalaluddin Rumi, and Ibn Arabi agree when they believe that "religious and intellectual experiences are too closely interwoven just like the interrelationship between gnosis (Karma-Samnyasa) and work (Karma Yoga)". In addition, although Schuon and Nasr are less influenced by the Gita compared to Coomaraswamy, they are also, to some degree, inspired by the Gita, especially in understanding the seemingly binary concept, Atman and Maya. The Perennial philosophers generally maintain that Atman is the Absolute or the Real whereas Maya is the Relative or the Illusory (Schuon 2007, p. 243). This general understanding is slightly changed apparently because of an encounter with the non-dualist paradigm introduced by the Bhagavad Gita.

\section{Atman and Maya}

The notion of Atman-Maya, among other things, is a topic that is frequently discussed by the Perennial philosophers. Through this concept, the influence of the Gita in their works can easily be traced. The dualists in whatever religion or philosophy generally suggest that Atman is the Absolute/the Real and Maya is the Relative/the Illusory. Meanwhile, the non-dualists are be able to find the elements of divinity within both Atman and Maya. The Perennialist philosophers encounter the non-dualistic paradigm through the works of Ananda K. Coomaraswamy. The dualism "Atman-Maya" becomes blurry when Comaraswamy explains the reality of Atman using the conception of the Bhagavad Gita. He explains that He (Atman) is "both inside and outside (bahir antas ca bhutanam), undivided in divided beings" (Coomaraswamy 2004b, p. 275). ${ }^{9}$ From this quotation, it is clear that the Bhagavad Gita, to some degree, shapes the Perennial-traditionalists' understanding, which normatively views things from the dualistic perspective, the real to the illusory or the esoteric to the exoteric oriented way of seeing.

Influenced by this non-dualistic perspective as well, Frithjof Schuon and Seyyed Hossein Nasr acknowledge the interrelationship between "the real" and "the illusory". According to them, there is no such thing called the real or the illusory. These two are interwoven and valuable. In contrast with the dualists' tenet, Schuon realizes that there is nothing unrelated to Atman as the Pure Light and the Primordial Principle. Even the object, the world, is also part of It (Schuon 2005b, pp. 191-92). He no longer views Maya as the illusory, but it is the manifestation, the radiation, and representation of Atman, because "Maya in a sense is also Atman". He explains, "... strictly speaking Maya in a sense also becomes Atman, since in the last analysis there is only Atman, therefore both poles must impinge on one another ... , in the sense that, in Atman, Maya is in a way prefigured, whereas Maya in its own fashion represents or reflects Atman" (Schuon 2005a, p. 535). Schuon adds that Atman can multiply

9 He refers to the verse 13.15 and 16, the verse 15.16 and 17, and the verse 18.20 from the Bhagavad Gita. 
into infinite forms of reality by means of Maya because it is also "the principle or the instrument of refraction and multiplication" (Schuon 2005a, p. 538).

In the same vein, Seyyed Hossein Nasr also no longer considers Maya as a mere Illusion. He then maintains that maya plays a double role as both veil and manifestation of the Real. On the one hand, maya could be a veil hindering humans from a comprehensive sight and understanding of the Atman. On the other hand, it could also be a manifestation, a theophany, of the Atman that reveals and manifests the One, Atman, upon "all planes of reality" (Nasr 2007b, p. 125.) In its role as the manifestation of Atman, S.H. Nasr (Nasr 2007b) observes that "Maya acts through radiation and reverberation or reflection, first preparing the ground or plane of manifestation, and then manifesting both the radiation and reverberation which take place on this plane". In this regard, there is a clear statement by S.H. Nasr that seems to be consciously or unconsciously inspired by the Bhagavad Gita. He states that "Maya is also creativity and Divine Play (lila)" (Nasr 2007b, p. 125). Although there is no further detailed explanation of the notion of Maya as the creative force in the realm of divine play, by saying the above, S.H. Nasr had already touched upon the basic non-dualistic idea of Maya in the Gita.

However, before formulating an early conclusion, let us examine whether the interpretation of those Perennial-traditionalists, represented by Coomaraswamy, Schuon, and S.H. Nasr, is grounded in the Gita. Firstly, Coormaraswamy's interpretation of God (Atman) within the Gita, which is conceived as the omnipresent and undivided being, is confirmed by the explanation of the Bhagavad Gita. In one of its verses, the Gita describes the omnipresence of the Atman as follows: "I am the Atman abiding in the heart of all beings. I am also the beginning, the middle, and the end of all beings" (The Bhagavad Gita, Verse 10.20, Prasad 1995). Another verse of the Gita also certainly confirms that Atman is the undivided, unmanifest, and unchangeable being: "Atman is said to have an unmanifest form and is incomprehensible and unchanging. Knowing this Atman as such you should not grieve" (The Bhagavad Gita, Verse 2.25, Prasad 1995).

In addition, the reading of Schuon and S.H. Nasr on the Gita-especially in the case of explaining the notion of Atman, Maya, and the relationship between the two-represents a significant move from the dualists' tenet. Although their general philosophy is primarily colored by dualism's world view, esotericism and exotericism, when it comes to the interpretation of the notion Atman-Maya, they dismantle this dualistic world view. Atman is understood not only in a transcendental sense, Atman as the unmanifest, but is also conceived in an immanent sense, in which Atman is recognized as everything, including Maya. This is certainly a valid interpretation of the Gita as the Gita itself is open to such interpretation. The Gita says that the Supreme encompasses everything, both Ksara (changeable) and Aksara (non-changeable) Purusha, ${ }^{10}$ both Apara (lower) and Para (higher) Prakriti, ${ }^{11}$ and also Maya. ${ }^{12}$ Their interesting interpretation of the Gita is that they regard Maya as "the principle or the instrument of refraction and multiplication" (Schuon) and as "creativity and Divine play (lila)" (S.H. Nasr). These two conceptions of Maya are founded upon the Gita's verses. In the Gita, Maya is understood as the creative force that differentiates the undifferentiated, divides the undivided, and renders Atman to multiply and manifest. The Gita explains the role of Maya in the process of creation in the following verse: "Though I am eternal, immutable, and the lord of all beings; yet I (voluntarily) manifest my own material nature and come into being by using my maya"13.

In short, the understanding of the relationship between Atman and Maya in the works of Coomaraswamy, Schuon, and Nasr reflects the influence of non-dualist interpretation of the Gita, which in fact resembles the Advaita's view of reality. The non-dualist approach of Coomaraswamy in reading the Bhagavad Gita, especially when he identifies the elements of divinity, immanence, and transcendence in both Atman and Maya as presented by the Gita, influences Schuon and Nasr.

\footnotetext{
The Bhagavad Gita, verse 15.16.

The Bhagavad Gita, verse 7.04-05.

The Bhagavad Gita, verse 4.06 .

The Bhagavad Gita, verse 4.06 .
} 
Both no longer perceive Maya as a mere illusion. For Schuon, Maya is a means of Atman's multiplication, and for Nasr, Maya is a manifestation of Atman.

\section{The Perennial-Non-Traditionalists' Approach Toward the Gita}

Besides the traditionalists' view of the Gita, another Perennialist approach towards the Gita is presented by the non-traditionalist writers such as Aldous Huxley (d. 1963) and Huston Smith (d. 2016). Unlike the traditionalists who are involved in the Perennial Philosophy movement as their spiritual-religious affinity, the non-traditionalists are associated with the movement more because of their scholarly works rather than their spiritual or religious affiliation. Furthermore, if the traditionalists are inspired by the Gita in the light of its non-dualistic paradigm, the non-traditionalists seem to be influenced by the Gita considering its "intermediary position". According to Huxley (1945), the Bhagavad Gita is firstly considered to be the intermediary text in the sense that it was written after the emergence of Upanishad's philosophy and before the birth of Samkhya's philosophy. In this regard, Aldous Huxley states that "the philosophy of the Upanishads reappears, is developed and enriched, in the Bhagavad Gita and is finally systemized, in the ninth century of our era, by Shankara" (Huxley 1945, p. 5). In the same vein, the Gita is also deemed the intermediary text in the sense that the most powerful teaching of the Gita is to provide different paths for human beings to attain God. Hence, the teaching of the Gita is intermediary regarding the position of human beings as the point of departure and God as the goal. In this respect, the non-traditionalists are more concerned with the Gita's explanation regarding the paths of liberation rather than its metaphysical or theological teachings. Therefore, their quotation, reference, and interpretation of the Gita are generally related to the issue of paths of human liberation (e.g., karma samnyasa/yjnana yoga, karma yoga, bhakti yoga, and raja yoga) rather than the reality of a thing (e.g., atman, maya, jivatma, ahamkara, prkrti, or guna.).

Aldous Huxley rebukes other philosophers and scholars of religion who maintain that there are only two ways leading to the delivering union with God, action and contemplation. Instead, he refers to the Bhagavad Gita and insists that there are three ways leading to the Supreme- the way of works, the way of knowledge, and the way of devotion. He says "In the Bhagavad Gita Sri Krishna instructs Arjuna in all three paths-liberation through action without attachment; liberation through knowledge of the Self and the Absolute Ground of all being which is identical; and liberation through intense devotion to the personal God or the divine incarnation" (Huxley 1945, p. 148).

In that quotation, Huxley interestingly excludes another path, which is also mentioned in the Gita, namely the path of meditation (Raja Yoga). He may consider the excluded path closely related to the path of knowledge or the path of love. However, more obviously, he excludes the path of meditation in his scheme of liberation because he wants to relate the paths of liberation with three basic human temperaments. By referring to Sheldon's classification of human temperaments, Huxley mentions three basic human traits-viscerotonic, somatotonic, and cerebrotonic-each of which has a natural-suitable path of liberation.

First, viscerotonic traits include the love of food, love of eating in common, love of comfort and luxury, love of ceremoniousness, love of people, love of childhood, craving for affection and social support, and need of people when in trouble. The suitable path for those who are dominated with these temperaments is the path of devotion (bhakti yoga). The over-extrovert tendency of these traits can be disciplined and canalized through bhakti yoga, so that "a merely animal gregariousness and a merely human kindliness becomes transformed into charity-devotion to the personal God and universal goodwill and compassion towards all sentient beings" (Huxley 1945, p. 152).

Second, somatotonic traits include the love for muscular activity, aggressiveness and lust of power, a love of combat and competitiveness, a high degree of physical courage, a nostalgic feeling for youth, and a need for activity when in trouble. The naturally suitable path for people that have a big portion of these temperaments is the path of work (Karma Yoga). The result of Karma Yoga is the correct action which, if it is trained and practiced, can direct human aggressiveness, self-assertion, and the lust for power into positive directions, such as a heroic act, a perseverance in being a champion, or a warrior 
and statesmanship character. In the path of work, however, one thing cannot be overlooked and separated, namely, the renunciation of the fruits of the work. The core virtue of the Karma Yoga is actually such freedom from the fruits of action.

Third, cerebrotonic traits include over-alertness, sensitive introversion, having little or no desire to dominate, wanting to live and let live, having a passion for intense privacy and solitary living, and nervousness, shyness, moodiness, and a restrained manner. The naturally appropriate path of liberation for people who are mostly leaning to these temperaments is the path of knowledge (Jnana Yoga). The ego-centered tendency and inward-looking orientation can be modified by this path to a consciousness that is centered upon the Supreme. The innate tendency towards introversion for its own sake will be transformed into thought, imagination, and self-analysis as ends. According to Huxley, this is the way to which the extreme cerebrotonic is naturally drawn (Huxley 1945, pp. 152-53).

Huxley's exposition of the Gita's paths of human salvation resembles the position of the Dvaita philosophical school concerning how humans can attain moksha (liberation). The Dvaita, which holds a dualistic view of reality (God as the Supreme Soul and individual souls being distinct), maintains that the liberation can be achieved through "through rigorous ethical and moral disciplines followed by right knowledge, right action, non-attachment, and devotional meditation on the Personal God (Vishnu)" (Bhaskarananda 2002). The emphasis and concentration on the Personal God in the aim of attaining liberation either through right knowledge, action, or devotion are apparent in Huxley and the Dvaita school of Vedantic philosophy. Each path of liberation is a valid method to achieve human liberation as far as it is devoted, directed, and dedicated to the Personal God.

In the same vein, Huston Smith in his discussion of Hinduism also emphasizes the paths of salvation. However, unlike Huxley, who simplifies the paths of salvation to three categories along with human temperaments and whose philosophical tenet is essentially analogous to the Dvaita school of philosophy, Smith mentions four ways to attain God: the way to God through knowledge, the way to God through love (devotion), the way to God through work (action), and the way to God through psychological exercises (meditation) (Smith 1965, pp. 32-61). The understanding of these four is, in fact, based on the Bhagavad Gita. This can be inferred from his statement saying that if one reads the Bhagavad Gita carefully, he will understand the following: "some realize the Atman through contemplation. Some realize the Atman philosophically. Others realize it by following yoga of the right action. Others worship God as their teachers have taught them" (Smith 1965, p. 61). Nevertheless, Smith regards those ways merely as means, as an intermediary, not an end. For (Smith 1965, pp. 48-49)), the ultimate end for a yogi is to shift from his finite self to his infinite self as well as to reach the level of what (Smith 1965, p. 64)) calls "the state of Sannyasin". He defines this state by referring to what the Bhagavad Gita says about the state of someone who "neither hates nor loves anything" (Smith 1965, p. 64).

In this regard, Smith's interpretation of the Gita is closer and analogous to the liberation paths of the Samkhya (sometimes written as Sankhya) school of philosophy. Samkhya is another dualist philosophical school in Hinduism. This school believes that Purusha (the soul) and Prakriti (unconscious primordial matter) are two different elements that constitute reality. However, Purusha is considered the real dimension of reality and Prakriti is deemed the illusory one. The task of a yogi is to distinguish the real from illusory and to liberate Purusha from the bondage caused by Prakriti through knowledge (viveka jnana) (Bhaskarananda 2002). That is the way in which humans can attain a real salvation and liberation from Samkhya's perspective. When Smith states that the ultimate end for a yogi is to shift the finite to the infinite self and to reach the level of Sannyasin, he implies that the main, or even the only, path leading humans to the liberation is the path of knowledge (jnana yoga). Other paths may bring humans to salvation, but they are only intermediary, leading to essential knowledge (viveka-jnana). This is the knowledge that can distinguish the infinite spirit (Purusha) from the finite reality (Prakriti) and help humans to renunciate the bondage of Prakriti and embrace the freedom of Purusha. This position is similar to Samkhya's philosophical tenet. 


\section{Conclusions}

From the above discussion, we can draw a conclusion that there are two ways of communication between the Perennialist scholars and the Bhagavad Gita. On one side, Perennial Philosophy scholars are both inspired and influenced by the Gita. On the other side, the Perennialists also have certain interpretations imposed on the Gita. The influence of the Gita can be seen in the works of the traditionalists-Ananda K. Coomaraswamy, Frithjof Schuon, and Seyyed Hossein Nasr-especially with respect to the non-dualist perspective of the Gita. If Coomaraswamy has already positioned himself as non-dualist in his writings from the beginning, Schuon and Nasr seem to be changing their view later after their encounter with the Gita. Schuon and Nasr are previously dualist in the sense that they always perceive a thing from the binary perspective, the Real to the Illusory, the Absolute to the relative, or the esoteric to the exoteric. This dualist tenet, however, seems to be changed and modified later by virtue of their encounter with the Gita. They start to think that Atman and Maya are not separated but interrelated. Maya is even considered as a part of the Atman. Maya, furthermore, is seen not only as the divine veil hampering the sight of the Absolute, but also as the manifestations leading to the knowledge of the Absolute. The most interesting change in their thinking is when they say that Maya is also a means of multiplication and of creation. This non-dualist tenet is analogous to the Advaita philosophical school within Hinduism that views the reality in a non-dualistic paradigm.

The non-traditionalist scholars, represented by Aldous Huxley and Huston Smith, tend to apply a dualist interpretation of the Gita rather than adopting its non-dualist paradigm. Their reading of the Gita also is similar to that of a certain dualist school within Hinduism. Huxley, who relates the paths of human liberation with human temperaments, represents the dualist tenets of the Dvaita's philosophical school. Meanwhile, Smith's interpretation of the Gita's paths of human liberation reflects the dualistic thought within the Samkhya philosophy.

Above all, the Bhagavad Gita is a unique text that can be approached and read from different perspectives. The Perennial philosophers, either the traditionalists or the non-traditionalists, have contributed an interesting perspective to the reading of the Gita. Some of them (Schuon and Nasr) may attempt to reconcile the tension between the dualist and non-dualist perspectives of the Gita in their interpretation. Although all of them are susceptible to misinterpretation, their attempts to bring the Gita into their community and targeted audiences deserve critical appreciation.

Funding: This research received no external funding and the APC was funded by Universitas Muhammadiyah Yogyakarta (UMY), Indonesia.

Conflicts of Interest: The author declares no conflict of interest.

\section{References}

Adhikari, Subhrashis. 2016. The Journey of Survivors: 70,000-Year History of Indian Sub-Continent. Bloomington: Partridge Publishing India.

Ashton, Geoffrey. 2014. Role Ethics or Ethics of Role-Play? A Comparative Critical Analysis of the Ethics of Confucianism and the Bhagavad Gītā. Dao 13: 1-21. [CrossRef]

Bhaskarananda, Swami. 2002. The Essentials of Hinduism A Comprehensive Overview of the World's Oldest Religion. Seatle: Viveka Press.

Burckhardt, Titus. 2003. Islamic Science. In The Essential Titus Burckhardt. Edited by William Stodart. Bloomingon: World Wisdom.

Coomaraswamy, Ananda K. 2004a. The Bugbear of Literacy. In The Essential Ananda K. Coomaraswamy. Edited by Arvind Sharma. Bloomington: World Wisdom.

Coomaraswamy, Ananda K. 2004b. The Hindu Tradition, Theology and Autology. In The Essential Ananda K. Coomaraswamy. Edited by Arvind Sharma. Bloomington: World Wisdom.

Coomaraswamy, Ananda K. 2004c. On the Pertinence of Philosophy. In The Essential Ananda K. Coomaraswamy. Edited by Rama P. Coomaraswamy. Bloomington: World Wisdom.

Coomaraswamy, Ananda K. 2007a. Paths That Lead to the Same Summit. In The Underlying Religion: An Introduction to the Perennial Philosophy. Edited by Martin Ling and Clinton Minaa. Bloomington: Wisdom World. 
Coomaraswamy, Ananda K. 2007b. Syplegades. In The Underlying Religion: An Introduction to the Perennial Philosophy. Edited by Martin Ling and Clinton Minaar. Bloomington: World Wisdom.

Davis, Richard H. 2015. Wilkins, Kasinatha, Hastings, and the First English Bhagavad Gita. International Journal of Hindu Studies 19: 39-57. [CrossRef]

Dhiman, Satinder. 2013. The Ethical and Spiritual Philosophy of the Bhagavad Gita: A Survey. Interbeing 6: 19-39.

Easwaran, Eknath. 2011. Essence of the Bhagavad Gita: A Contemporary Guide to Yoga, Meditation, and Indian Philosophy. Tomales: Nilgiri Press.

Eder, Milton. 1988. A Review of Recent “Bhagavad Gita” Studies. Journal of South Asian Literature 23: 20-46.

Gonda, Jan. 1969. Aspects of Early Visnuism. Delhi: Motilal Banarsidass Publishers.

Huxley, Aldous. 1945. The Perennial Philosophy. New York and London: Harper and Brothers Publishers.

Kriyananda, Swami, and Paramahansa Yogananda. 2006. The Essence of the Bhagavad Gita. Nevada City: Crystal Clarity Publishers.

McLain, Karline. 2019. Living the Bhagavad Gita at Gandhi's Ashrams. Religions 10: 619. [CrossRef]

Minaar, Clinton, and Martin Ling. 2007. The Underlying Religion: An Introduction to the Perennial Philosophy. Bloomington: World Wisdom.

Muller, Friedrich Max. 1903. The Life and Letters of the Honourable Friedrich Max Muller in Two Volumes. Edited by Georgina Adelaide Muller. Bombay, London and New York: Longmans, Green and Company.

Nasr, Seyyed Hossein. 2007a. Living in Multi-Religious World. In The Essentials of Seyyed Hossein Nasr. Edited by William C. Chittick. Bloomington: World Wisdom.

Nasr, Seyyed Hossein. 2007b. Scientia Sacra. In The Underlying Religion: An Introduction to the Perennial Philosophy. Edited by Martin Ling and Clinton Minaar. Bloomington: World Wisdom.

Nasr, Seyyed Hossein. 2007c. The Traditionalist Approach to Religion. In The Essentials Seyyed Hossein Nasr. Edited by William C. Chittick. Bloomington: World Wisdom.

Patil, G. M. 1960. Upanisadic References in Bhagavad Gita. Annals of the Bhandarkar Oriental Research Institute 41: 66-72.

Rambachan, Anantanand. 2006. The Advaita Worldview: God, World, And Humanity. Albany: State University of New York Press.

Schuon, Fithjof. 2005a. Sophia Perennis. In The Esentials of Frithjof Schuon. Edited by Seyyed Hossein Nasr. Bloomington: World Wisdom.

Schuon, Frithjof. 2005b. Hinduism. In The Esentials of Frithjof Schuon. Edited by Seyyed Hossein Nasr. Bloomington: World Wisdom.

Schuon, Frithjof. 2005c. The Nature of Religion. In The Esentials of Frithjof Schuon. Edited by Seyyed Hossein Nasr. Bloomington: World Wisdom.

Schuon, Frithjof. 2007. The Perennial Philosophy. In The Underlying Religion: An Introduction to the Perennial Philosophy. Edited by Martin Ling and Clinton Minaar. Bloomington: World Wisdom.

Shideler, Emerson W. 1960. The Meaning of Man in the Bhagavad Gita. Journal of Bible and Religion 28: 308-16. [CrossRef]

Sinha, Mishka. 2010. Corrigibility, Allegory, Universality: A History of the Gita's Transnational Reception, 785-1945. Modern Intellectual History 7: 297-317. [CrossRef]

Smith, Huston. 1965. The Religions of Man. New York: Harper and Row, Perennial Library.

Stroud, Scott R. 2005. Ontological Orientation and The Practice of Rhetoric: A Perspective From Bhagavad Gita. The Southern Communication Journal 70: 146-60. [CrossRef]

Theodor, Ithamar. 2017. Rebirth According to the Bhagavad gita; Epistemology, Ontology and Ethics. Religions 8: 148. [CrossRef]

Prasad, Ramananda. 1995. The Bhagavad Gita. Translated by Ramananda Prasad. Fremont: The American Gita Society.

Vivekananda, Swami. 1986. Vedanta, Voice of Freedom. St. Louis: The Vedanta Society of St. Louis.

(C) 2020 by the author. Licensee MDPI, Basel, Switzerland. This article is an open access article distributed under the terms and conditions of the Creative Commons Attribution (CC BY) license (http://creativecommons.org/licenses/by/4.0/). 